Gut, 1965, 6, 48

\title{
Autoantibodies in simple atrophic gastritis
}

\author{
N. F. COGHILL, D. DONIACH ${ }^{1}$, I. M. ROITT ${ }^{2}$, D. L. MOLLIN ${ }^{2}$, AND \\ A. WYNN WILLIAMS ${ }^{3}, 4$ \\ From the West Middlesex Hospital, Isleworth, the Middlesex Hospital \\ Medical School, London, the Department of Haematology, the Postgraduate \\ Medical School of London, Hammersmith Hospital, and the Department of Pathology, \\ University of Edinburgh
}

EDITORIAL SYNOPSIS The authors have examined a group of 47 patients who had been found to have chronic gastritis, in nine superficial and in 38 atrophic. Patients with pernicious anaemia were excluded and in only two was there a doubtful family history of pernicious anaemia. A relatively high incidence of autoantibodies to the parietal cells of the stomach was found. In no case, however, were there antibodies to intrinsic factor, though these were detected in nearly $60 \%$ of patients with pernicious anaemia. Interesting correlations were found between the parietal cell antibodies and such factors as the degree of loss of parietal cells, the severity of the gastric secretory defect, and the presence of thyroid antibodies.

Recent work has shown that the majority of adult patients with Addisonian pernicious anaemia have autoantibodies in their blood reacting specifically with the parietal cells of the gastric mucosa (Irvine, Davies, Delamore, and Williams, 1962; Taylor, Roitt, Doniach, Couchman, and Shapland, 1962; Markson and Moore, 1962b). Autoantibodies against gastric intrinsic factor itself have been demonstrated in the blood of $40 \%$ of patients with pernicious anaemia by a test in vivo (Taylor, 1959a; Schwartz, 1960), and by an electrophoretic retention method in vitro (Jeffries, Hoskins, and Sleisenger, 1962; Taylor et al., 1962). Recently new methods in vitro for the detection of antibodies to intrinsic factor have been introduced by Abels, Bouma, Jansz, Woldring, Bakker, and Nieweg (1963) and Ardeman and Chanarin (1963). The latter reported finding such antibodies in $57 \%$ of a group of patients with pernicious anaemia and this has been confirmed by Roitt, Doniach, and Shapland (1964).

That there may be a connexion between gastritis and thyroiditis is suggested by the finding of pernicious anaemia and hypothyroidism (atrophic thyroiditis) in the same patient, first described by Charcot in 1881 (Tudhope and Wilson, 1960, 1962; McNicol, 1961; Williams and Doniach, 1962) and

\footnotetext{
In receipt of a grant from the British Empire Cancer Campaign. ${ }^{2}$ In receipt of a grant from the Medical Research Council.

${ }^{3}$ In receipt of a grant from the Secretary of State for Scotland.

4Present address: Pathology Department, University of Otago, Dunedin, New Zealand.
}

by the frequent coexistence of thyroid and gastric antibodies in patients with pernicious anaemia and with thyroid diseases (Irvine et al., 1962; Markson and Moore, 1962a; Doniach, Roitt, and Taylor, 1963). This view is strengthened by the presence of a high incidence of antibodies to both gastric mucosa and thyroid tissue, as well as lesions in these organs, in the families of patients with either pernicious anaemia or thyroiditis (Doniach, Roitt, and Taylor, 1964).

Adams, Glen, Kennedy, Mackenzie, Morrow, Anderson, Gray, and Middleton (1964) investigated a group of 20 patients known to possess parietal cell antibodies. They found varying degrees of atrophic gastritis in 18 (severe in nine) and histaminefast achlorhydria in eight. Mackay (1964) found antibodies to gastric mucosal antigen in 50 to $60 \%$ of patients with atrophic gastritis.

We have found atrophic gastritis of varying severity in patients with dyspepsia or anaemia who have neither peptic ulcers nor Addisonian pernicious anaemia. In a great many of these cases the histological appearance of the gastric mucosa cannot be distinguished from that of pernicious anaemia. Some of these patients have partially defective vitamin $B_{12}$ absorption and their relationship to Addisonian pernicious anaemia has recently been investigated by Whiteside, Mollin, Coghill, Williams, and Anderson (1964). We have looked for gastric and thyroid autoantibodies and for non-organ-specific reactions such as antinuclear factors and non-organ-specific 
complement fixation, in a group of such patients. Gastric function studies had already been carried out in these patients in the course of the previous study and as before we excluded patients who might have been suffering from early pernicious anaemia and patients with an established family history of this disease. For comparison a group of patients with hypochromic anaemia in whom gastric biopsy showed a normal mucosa, and a group of healthy controls, were examined by the same serological tests.

\section{MATERIALS AND METHODS}

PATIENTS WITH GASTRITIS Forty-seven patients with atrophic gastritis were selected on grounds of availability. In many of them the atrophic gastritis was severe with defective, or partially defective, absorption of radioactive vitamin $\mathbf{B}_{12}$. Gastric biopsy specimens were examined from the body of the stomach in each case by the method of Wood, Doig, Motteram, and Hughes (1949) using a modified gastric biopsy tube (Coghill and Williams, 1955). In 10 patients a single specimen was obtained; in the rest two or (frequently) more specimens were obtained. The classification of gastritis used was that of Williams, Edwards, Lewis, and Coghill (1957) and Whiteside et al. (1964).

There were nine patients with chronic superficial or mixed gastritis (three male and six female) aged from 31 to 74 years (mean 59), and 38 patients with chronic atrophic gastritis (13 male and 25 female) aged from 23 to 79 years (mean 58). Of the patients with superficial or mixed gastritis four females suffered from hypochromic anaemia, one female had had a partial gastrectomy, and four (one female and three males) had nonulcer dyspepsia (one with ulcerative colitis). Of the men with atrophic gastritis nine suffered from non-ulcer dyspepsia, two from hypochromic anaemia, one had had a gastric ulcer, one a partial gastrectomy, and one had had gastric erosions with gastroscopic suggestion of atrophic gastritis. Of the women with atrophic gastritis, 18 suffered from hypochromic anaemia due to various causes, five from non-ulcer dyspepsia, and two from folic-acid deficient megaloblastic anaemia. The serum $B_{12}$ concentrations in these two patients were respectively 230 and $175 \mu \mu \mathrm{g} . / \mathrm{ml}$. when they were first seen and have remained normal. One of the female patients with hypochromic anaemia had myxoedema.

The results of gastric function studies on all except four of these patients have already been reported (Whiteside et al., 1964). There was a doubtful family history of pernicious anaemia in two of the patients in the present series: in both the absorption of radioactive vitamin $B_{12}$ was entirely within normal limits.

The gastric biopsy specimens were examined by one of us (A.W.W.) without knowledge of the results of all the other investigations performed in these patients. In each case an assessment was made of the severity of the atrophy, the state of the surface epithelium, the number of parietal cells, the degree of infiltration of the mucosal stroma with chronic inflammatory cells, and the presence of intestinal heterotopia.

PATIENTS WITH IRON-DEFICIENT ANAEMIA AND A NORMAL GASTRIC MUCOSA There were 23 women aged 23-79 years (mean 45) in this group, and three men aged 31, 47, and 53 years.

HEALTHY CONTROL SUBJECTS These were taken from a group obtained in the course of previous studies on pernicious anaemia (Taylor et al., 1962) and were selected for age and sex to match the patients with atrophic gastritis.

SERUM VITAMIN $\mathbf{B}_{12}$ CONCENTRATIONS These were measured in 46 patients with atrophic gastritis by microbiological assay, using either the bacillaris or the $z$ strain of Euglena gracilis (Ross, 1952; Hutner, Bach, and Ross, 1956). Concentrations in health range from 140 to $960 \mu \mu \mathrm{g} . / \mathrm{ml}$.; patients with pernicious anaemia have levels of less than $100 \mu \mu \mathrm{g} . / \mathrm{ml}$. (Mollin and Ross, 1954). In all cases the serum $B_{12}$ concentration was measured at the same time as the tests for antibodies.

ABSORPTION OF RADIOACTIVE VITAMIN $\mathbf{B}_{12}$ This was measured in 43 patients with atrophic gastritis (14 male and 29 female) by the faecal excretion technique described by Booth and Mollin (1956) and/or by the hepatic uptake method (Glass, Boyd, Gellin, and Stephanson, 1954). Absorption tests were performed near the time of gastric biopsy (when patients were no longer suffering from hypochromic anaemia, gastric ulcer, or myxoedema), and repeated subsequently in some patients. In only a few patients could they be repeated at the time of tests for antibodies. In the majority absorption of radioactive $B_{12}$ was tested three years or less before the investigations for antibodies. The results given in this paper are those nearest in time to the antibody tests.

Oral test doses of $1.0 \mu \mathrm{g}$. of ${ }^{58} \mathrm{Co}$-labelled $\mathrm{B}_{12}$ were used. Young normal subjects usually absorb about $0.5 \mu \mathrm{g}$. of this dose or more (Mollin, unpublished data). Control subjects of varying ages absorb from 0.26 to $0.98 \mu \mathrm{g}$. They absorb more than $0.5 \mu \mathrm{g}$. if the dose of $B_{12}$ is accompanied by a subcutaneous injection of $0.25 \mathrm{mg}$. of carbamyl choline chloride (Carbachol) (Mollin, Booth, and Baker, 1957). Patients with pernicious anaemia absorb from 0 to $0.28 \mu \mathrm{g}$., $83 \%$ absorbing less than $0.20 \mu \mathrm{g}$., and absorption is not improved by Carbachol. The method used for measuring $B_{12}$ absorption in our cases was that described by Whiteside et al. (1964).

The patients were divided according to their power to absorb radioactive vitamin $\mathbf{B}_{\mathbf{1 2}}$ as follows:-

1 No defect $0.5 \mu \mathrm{g}$. or more was absorbed when the dose was given alone.

2 Mild defect 0.29 to $0.49 \mu \mathrm{g}$. was absorbed when the dose was given alone.

3 Moderate defect Less than 0.29 $\mu \mathrm{g}$. was absorbed when the dose was given alone, but substantially more was absorbed when the dose was given with Carbachol.

4 Severe defect Less than $0.29 \mu \mathrm{g}$. was absorbed when the dose was given alone or with Carbachol. 
GASTRIC ACIDITY The gastric juice was sampled in 43 patients by the technique described by Kay (1953). In 40 patients maximal histamine stimulation was used by the method of Kay (1953), but only $75 \mathrm{mg}$. of mepyramine maleate was injected. In three patients $0.5 \mathrm{mg}$. histamine was given. The $p \mathrm{H}$ of the gastric juice was measured electrometrically. In four patients who were unable to swallow a tube a tubeless test was performed using an ion-exchange resin containing azure $\mathrm{A}^{\mathbf{1}}$, and with maximal histamine stimulation. Haematological methods described by Dacie (1956) were used.

SEROLOGICAL TESTS Certain serological tests were also employed.

Gastric antibodies The presence of parietal cell antibodies was investigated by the immunofluorescent test and its titre determined by complement fixation using a ficin-treated gastric mucosal preparation as antigen (Taylor et al., 1962; Baur, Roitt, and Doniach, 1965). The electrophoretic retention test of Jeffries et al. (1962), as applied by Taylor $e$ al. (1962), and the vitamin $B_{12}$ transfer reaction (Ardeman and Chanarin, 1963) were used to demonstrate antibodies to gastric intrinsic factor.

Thyroid antibodies The presence of thyroid antibody was investigated by immunofluorescence, tanned red cell agglutination, and complement-fixation tests as described previously (Doniach and Roitt, 1963). Titres were classed as low when only the fluorescent tests for antibodies to the colloid and epithelial cell cytoplasm were positive (these

${ }^{1}$ A methacrylic carboxylic acid resin (Amberlite IRC-50) with azure A (Instituto Sieroterapico 'Sclavo', Siena, Italy). are frequently found together), or when the serum reacted to titres not exceeding 1/250 with thyroglobulin-coated tanned red cells. Patients with moderate or high thyroid antibody titres had a positive complement-fixation test with thyroid microsomes and in some cases also a high tanned cell titre as well as giving fluorescence of the colloid and cytoplasm.

Antinuclear factors These were detected by the immunofluorescent tests on fixed and unfixed thyroid sections and unfixed gastric mucosa, using an antihuman- $\gamma$-globulin conjugate known to react with both $7 \mathrm{~S}$ and $19 \mathrm{~S}$ globulins. This method may give a relatively high incidence of positive reactions as it detects traces of 19S anti-nuclear factors which have no clinical significance. The titre was determined by repeating the tests on serum dilutions of $1 / 10,1 / 20,1 / 50$, and $1 / 100$.

Non-organ-specific complement-fixation This was determined with fresh rat liver homogenates using 2 M.H.D. of complement in the test.

\section{RESULTS}

AUTOANTIBODIES The Table summarizes the results of tests for antibodies to stomach, thyroid, and cell nuclei in the three groups of patients studied and, for comparison, in patients with pernicious anaemia.

Gastric antibodies None of the patients with atrophic gastritis had any detectable antibodies to intrinsic factor in contrast to a $60 \%$ incidence of these antibodies in patients with pernicious

\section{TABLE}

INCIDENCE OF AUTOANTIBODIES IN 47 PATIENTS WITH ATROPHIC GASTRITIS, IN THEIR MATCHED CONTROLS, IN 26 CASES OF HYPOCHROMIC ANAEMIA WITH NORMAL GASTRIC MUCOSA, AND IN 191 CASES OF PERNICIOUS ANAEMIA Antibodies

Patients

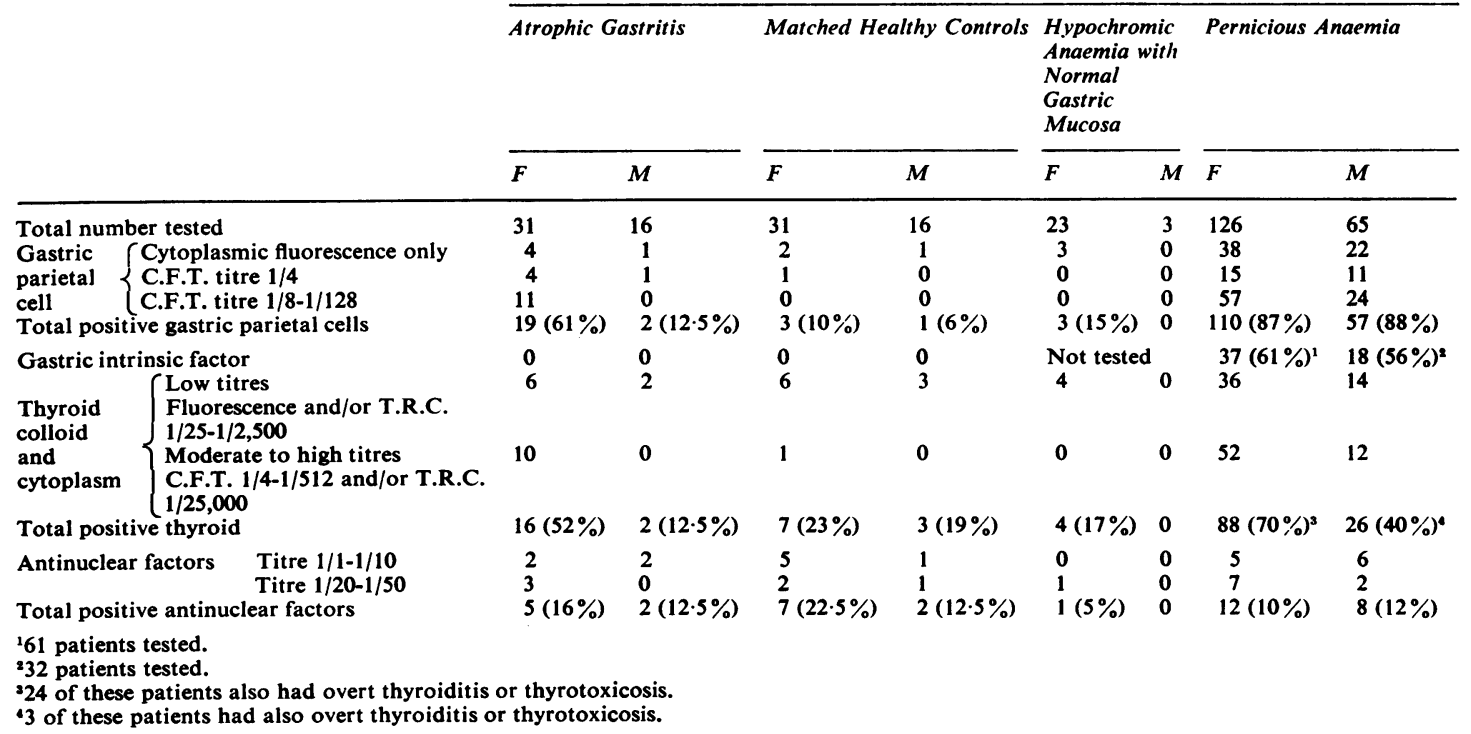



16 MALES
31 FEMALES
PARIETAL CELL ANTIBODIES
NEGATIVE
POSITIVE

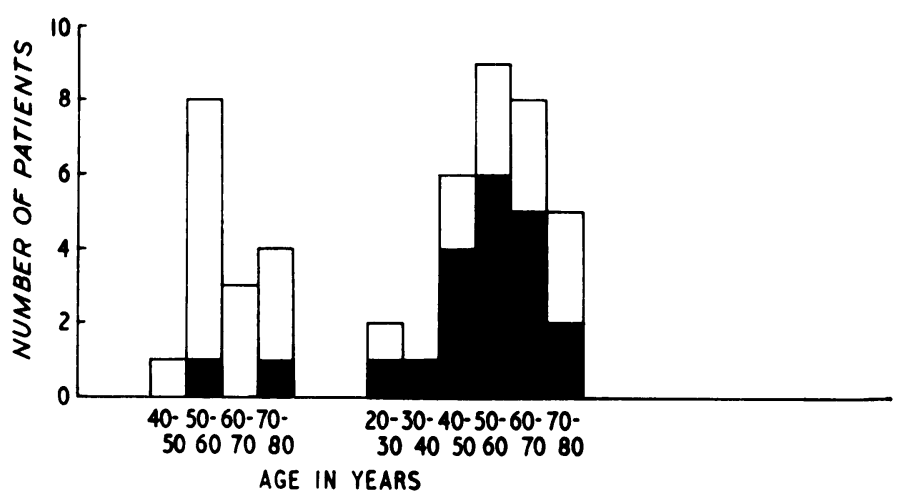

FIG. 1. Age and sex distribution and parietal cell antibodies in 47 patients who had atrophic gastritis without pernicious anaemia.

anaemia. However, antibodies to gastric parietal cells were found.

The relationship between the age and sex of the patients and the results of the gastric antibody tests are shown in Figure 1. In the atrophic gastritis group $62 \%$ of the female patients had gastric parietal cell antibody, in over half of moderate to high titre, with a complement-fixation test positive up to serum dilutions of $1: 128$. Among the men only two $(12.5 \%)$ reacted with gastric antigen, at low titre only. About $10 \%$ of healthy controls of both sexes had parietal cell antibodies all of low titre. Three of the 23 women with hypochromic anaemia but normal gastric mucosa reacted with parietal cells: all gave very weak reactions in the fluorescent test. These results compare with an incidence of parietal cell antibody of $88 \%$ in patients with pernicious anaemia (see Table).

Thyroid antibodies Weak reactions are found in

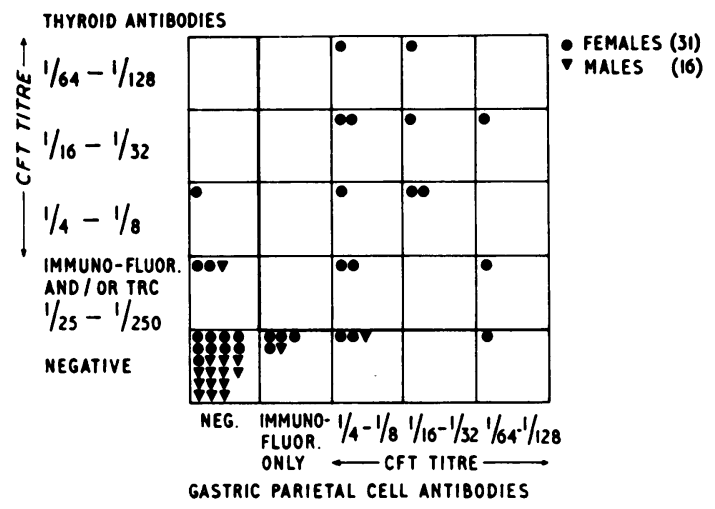

FIG. 2. Correlation of gastric and thyroid antibodies in 47 patients with atrophic gastritis. about $23 \%$ of elderly control subjects (Doniach and Roitt, 1964). The female patients with atrophic gastritis had both a high incidence and high titres of thyroid specific antibodies, whereas in the men with atrophic gastritis and the patients with hypochromic anaemia and normal gastric mucosa the incidence of thyroid antibodies was not greater than in the controls, and the reactions were weak. Sixteen of the 31 female patients $(52 \%)$ with atrophic gastritis gave positive results by one or more tests: low titres were found in six cases but in 10 the complement-fixation test was positive and in half of these the titre was $1 / 32$ or greater indicating a significant degree of active lymphoid thyroiditis (Doniach and Roitt, 1963). Thyroglobulin antibodies were less common: the tanned red cell test was positive in eight patients of whom only two had titres of $1 / 2,500$ and $1 / 250,000$ respectively, while six had lower titres not exceeding $1 / 250$. This predominance of cytoplasmic antibodies has also been found in pernicious anaemia. Furthermore nearly $40 \%$ of our patients with gastritis had both gastric and thyroid antibodies simultaneously, particularly those with high titres (Fig. 2). The comparable incidence in pernicious anaemia is $53 \%$. Of those patients with atrophic gastritis who possessed gastric antibodies nearly two-thirds also had thyroid antibodies (Fig. 2). In pernicious anaemia the proportion is the same (unpublished data).

Non-organic-specific antibodies The incidence of positive reactions for antinuclear factors was not increased above the control level in any of the groups, and all positive tests were of weak titre $(1 / 10$ to $1 / 50)$. Their frequency was unexpectedly common in the elderly controls, giving an overall incidence of $20 \%$. There were fewer positive reactors $(14 \%)$ 
among the patients of both sexes with atrophic gastritis but the difference is not significant in view of the small size of the group and the high sensitivity of the test. Both diffuse and speckled patterns of nuclear staining were found, but no nucleolar antibodies were seen. The incidence of non-organspecific complement-fixation reactions with rat liver was low in all groups, including the controls.

Gastric mucosal appearances and gastric antibodies in patients with atrophic gastritis There was no correlation between the appearances of the mucosal surface epithelium, the degree of intestinal heterotopia and the amount of small inflammatory cell infiltration in the mucosal stroma, and the presence of gastric antibodies. There were 17 women with a slight to moderate number of inflammatory cells of whom 11 had gastric antibodies, and of 11 women with considerable cellular infiltration seven had

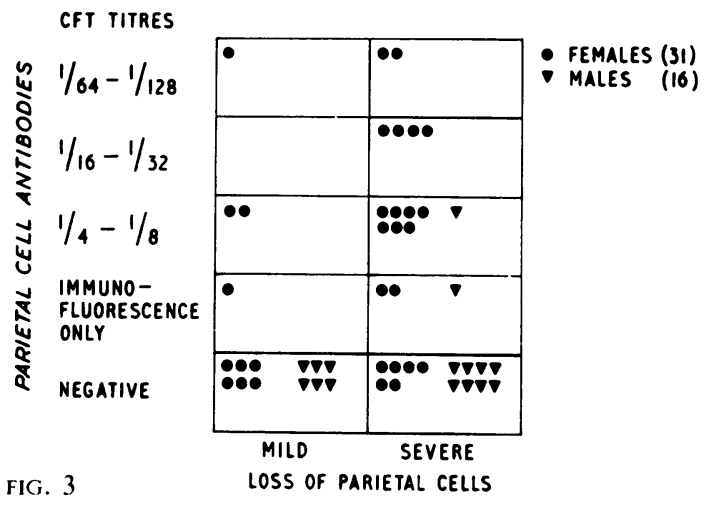

antibodies. Of the two men with antibodies one had few and the other numerous infiltrating cells. There was some correlation between loss of parietal cells and the presence of gastric antibodies (Fig. 3). The overall degree of atrophy also paralleled the presence of antibodies but only in the female patients (Fig. 4).

GASTRIC FUNCTION TESTS Three tests were used to estimate gastric function.

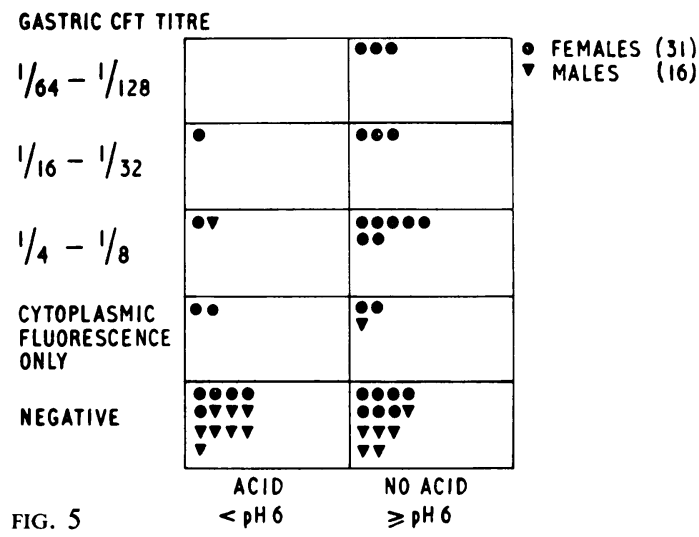

Gastric acidity Those in whom the gastric juice $p \mathrm{H}$ was 6.0 or above, or who had a negative tubeless augmented histamine test, were classed as secreting no gastric $\mathrm{HCl}$. In this group there were four patients with superficial or mixed gastritis and 25 with atrophic gastritis. Antibodies were more

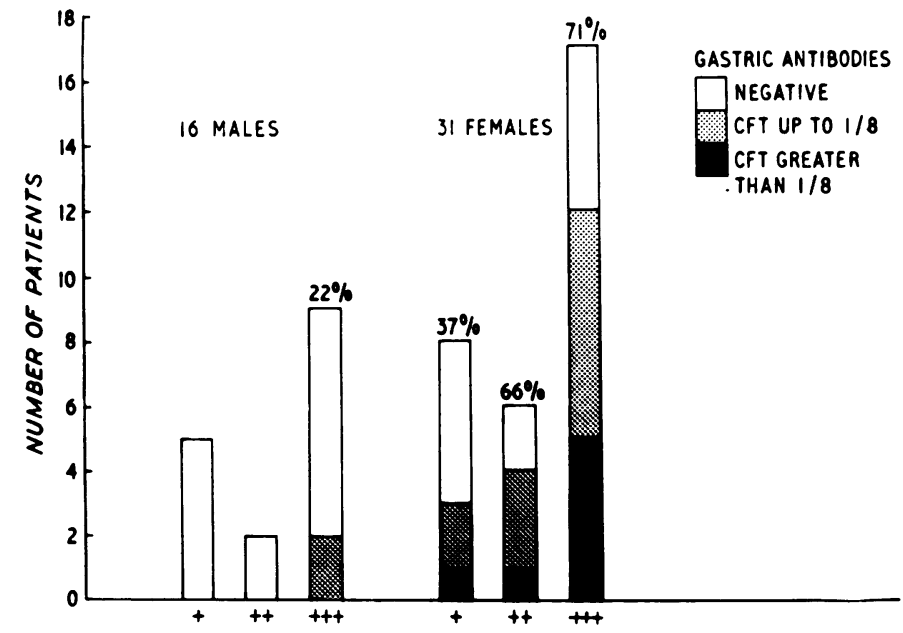

DEGREE OF MUCOSAL ATROPHY ON GASTRIC BIOPSY
FIG. 3. Correlation of parietal cell loss in biopsy specimens with gastric antibodies in 16 males and 31 females with atrophic gastritis.

FIG. 4. Correlation of histological degree of mucosal atrophy with parietal cell antibodies in patients with atrophic gastritis.

FIG. 5. Correlation of gastric juice $\mathrm{pH}$ after histamine with the presence of parietal cell antibodies in 47 patients with atrophic gastritis.

FIG. 4 


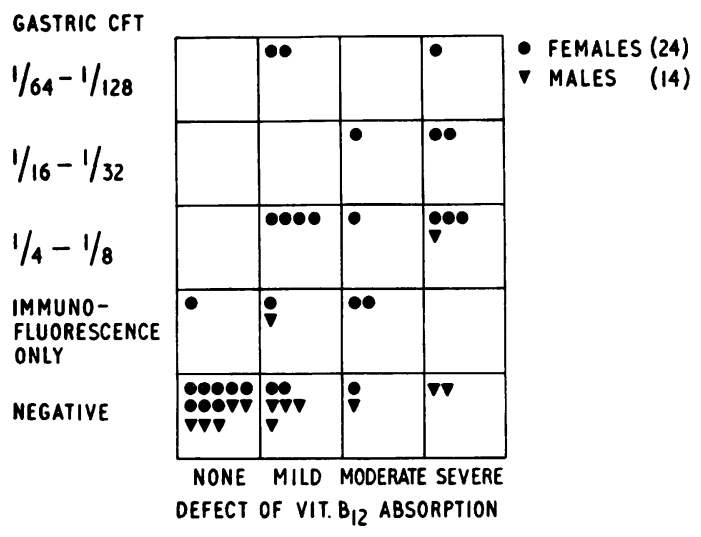

FIG. 6. Relationship of radiovitamin $B_{12}$ absorption defect, as defined, to parietal cell antibodies in atrophic gastritis.

common and of higher titre in patients in whom the $p \mathrm{H}$ of the gastric juice was above 6.0 after histamine (Fig. 5). The patients with hypochromic anaemia and normal gastric mucosa all secreted gastric $\mathrm{HCl}$. Gastric function tests were not done in the control subjects.

Absorption of radioactive vitamin $B_{12}$ There was some correlation between severity of absorption defect and gastric parietal cell antibody titre in patients with gastritis (Fig. 6). Only one patient with normal absorption of radiovitamin $B_{12}$ possessed parietal cell antibodies. But 11 out of 15 patients with moderately or severely defective radio- $\mathrm{B}_{12}$ absorption, some as severe as in pernicious anaemia, possessed gastric antibodies. One patient, a woman now aged 44, suffers from primary myxoedema and her mother has Hashimoto's disease. Five years ago she absorbed $0.80 \mu \mathrm{g}$. of a $1.0 \mu \mathrm{g}$. dose of radio- $\mathrm{B}_{12}$ given alone and her stomach secreted $\mathrm{HCl}$. Now she was found to absorb $0.36 \mu \mathrm{g}$. of radio- $\mathrm{B}_{12}$ given alone, and on maximal histamine stimulation (gastric tube sited under fluoroscopy) her stomach no longer secreted $\mathrm{HCl}$. She had gastric antibodies in high titre (complement-fixation test $1 / 128$ ).

Serum vitamin $B_{12}$ levels These levels were subnormal in nine patients with gastritis (females: $85,95,115,120$ and 130 ; males: $90,110,115$, and $130 \mu \mu \mathrm{g} . / \mathrm{ml}$. respectively). Three of the female patients possessed parietal cell antibodies. The patient with the lowest serum $B_{12}$ level had the highest antibody titre (complement-fixation test 1/64). The four men with subnormal serum levels of vitamin $\mathbf{B}_{\mathbf{1 2}}$ had no demonstrable gastric antibodies. The man with the lowest $B_{12}$ level had had a terminal iliectomy for carcinoma of the caecum and this may have influenced his radio- $\mathrm{B}_{12}$ absorption, which was severely defective, but is not included in the above results.

\section{DISCUSSION}

The histological picture of atrophy and inflammatory cell infiltration of the gastric mucosa found in patients with atrophic gastritis bears a striking resemblance to the histological appearances in chronic atrophic thyroiditis (primary adult myxoedema) which is thought to result from an autoaggressive immune process. This has led to the suggestion that gastritis might also be produced by an autoimmune mechanism (Taylor, 1959b; Williams, 1960).

The finding of parietal cell antibodies in patients with simple atrophic gastritis and in patients with pernicious anaemia supports this view, and the additional finding of thyroid antibodies in these two conditions indicates that there may be some relationship between them and thyroiditis.

Our results show some correlation between the degree of gastric atrophy and the presence of parietal cell antibodies (Fig. 4), despite the sampling error inherent in the biopsy technique, and the fact that the biopsy specimens were obtained in some cases three or more years before the serological tests. Sampling errors are largely avoided in the measurement of gastric $\mathrm{HCl}$ production and radiovitamin $B_{12}$ absorption and the results of these tests correlated better with gastric antibodies (Figs. 5 and 6). These findings support the suggestion that there is some relationship between simple atrophic gastritis and pernicious anaemia. That this relationship may nevertheless be limited is shown by the incidence of antibody to parietal cells being lower than that found in pernicious anaemia and by the absence of antibody to intrinsic factor in all our cases of simple atrophic gastritis. Furthermore the incidence of gastric antibodies was considerably higher in female than in male patients with atrophic gastritis, unlike the situation in pernicious anaemia. The reason for this sex difference in atrophic gastritis was not clear but there are at least four possible explanations. 1 Only a small number of men were available for study and in many gastric function was not greatly depressed. 2 Atrophic gastritis in males could be due to different factors unconnected with autoimmunity. The causes of atrophic gastritis remain undetermined but may well be multiple (Coghill, 1960); we have no valid data on this point in these patients. 3 Men with atrophic gastritis may develop autoimmunity but could be less effective producers of circulating antibodies. This is not borne out by experience. While autoimmune diseases in general are much less common in men, affected 
males show antibody titres as high as females. In pernicious anaemia although the sex ratio was roughly two females to one male in our series of 191 cases, the incidence of parietal cell and intrinsic factor antibodies was similar in the two sexes. However, more of the females had associated high thyroid antibody titres. Similarly in Hashimoto's disease, in which the sex ratio is 12 females to 1 male, analysis of 570 cases showed that high titre antibodies were even more common among the males (Doniach and Roitt, 1963). 4 The men were selected by different clinical criteria and therefore might not be comparable with the female group. This may be more relevant. The majority of our female patients with atrophic gastritis presented with hypochromic anaemia whereas most of the males were investigated for some form of dyspepsia. Although it is known that both iron-deficiency anaemia and non-ulcer dyspepsia may be associated with a gastric atrophy of similar histological appearance to that in pernicious anaemia, the role of autoimmunity has not yet been adequately studied in these two conditions. In the female patients with atrophic gastritis we found almost as many with thyroid antibodies and overt past and present thyroid disease as in cases of pernicious anaemia (Doniach et al., 1963). In contrast the men with atrophic gastritis showed no increase relative to controls, again suggesting that we may have been dealing with a distinct collection of patients.

If pernicious anaemia may be compared with primary myxoedema, then atrophic gastritis without anaemia is analogous to chronic multifocal thyroiditis which rarely progresses to complete loss of thyroid function. More often this form of thyroiditis gives rise to a chronic mild hormonal deficiency, a state comparable with the defect of intrinsic factor production found in atrophic gastritis but which rarely causes pernicious anaemia (Wood, Ralston, Ungar, and Cowling, 1964; Whiteside et al., 1964). Similarly the mild or subclinical defects in Hashimoto goitre, or Grave's disease with multifocal thyroiditis, may become overt after partial thyroidectomy and this is paralleled by the increased risk of megaloblastic anaemia following partial gastrectomy in patients with atrophic gastritis (MacLean, 1957; Deller and Witts, 1962).

It is possible that one cause of pernicious anaemia in patients with simple atrophic gastritis: whose intrinsic factor secretion is already reduced, is the neutralization of intrinsic factor by antibodies either in the intestine or at its site of production. The absence of antibody to intrinsic factor in simple atrophic gastritis may explain why it infrequently causes pernicious anaemia. If simple atrophic gastritis by itself rarely results in pernicious

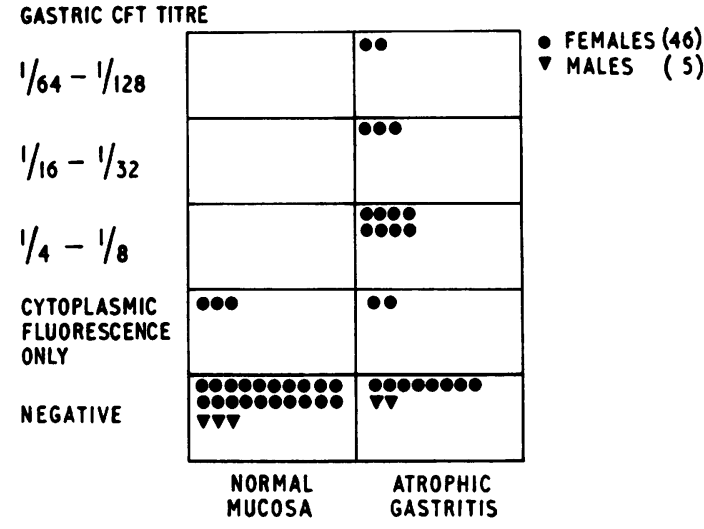

FIG. 7. Hypochromic anaemia: gastric histology correlated with parietal cell antibodies.

anaemia an additional factor must be involved in the pathogenesis of this condition.

Not all patients with Addisonian pernicious anaemia possess demonstrable antibodies to intrinsic factor; the reported incidence of these antibodies varies from 40 to $60 \%$, according to the technique used (Roitt et al., 1964). That they are not found in all patients with pernicious anaemia does not exclude them as a factor in pathogenesis. The absence of demonstrable antibodies to intrinsic factor in some patients with pernicious anaemia may be due to inadequacies in the serological tests, or to a low level of antibody synthesis, or to failure of antibody to spill over into the circulation owing to combination with antigen. However it is possible that in these negative individuals tissue destruction is cell-mediated and not dependent on humoral antibodies. A few of these patients may merely have had simple atrophic gastritis for a very long time.

It is still uncertain how far simple atrophic gastritis is a progressive process. That it may be so, in individual cases, is shown by our patient who had no family history of pernicious anaemia but possessed high titres of antibodies to gastric (and thyroid) tissue. This patient, whose mother has Hashimoto's disease and who herself suffers from myxoedema, lost the power to secrete gastric $\mathrm{HCl}$, and her ability to absorb radiovitamin $\mathrm{B}_{12}$ was more than halved, over a five-year period.

There is a higher incidence of gastric antibodies among patients with hypochromic anaemia than in control subjects (Markson and Moore, 1962b). Gastric antibodies were only present in such patients when the iron deficiency was accompanied by gastric atrophy (Dagg, Goldberg, Anderson, Beck, and Gray, 1964), and our results confirm this finding 
(Fig. 7). Parietal cell antibodies were found almost exclusively in the patients with hypochromic anaemia who also had atrophic gastritis. Since there were only two men with hypochromic anaemia and atrophic gastritis, neither of whom had antibodies, it is impossible to evaluate the presence of a sex difference in this series. Although it is possible that iron deficiency contributes to the development of atrophic gastritis (Witts, 1956; Badenoch, Evans, and Richards, 1957) there is evidence that gastritis may often precede hypochromic anaemia (Coghill, 1960). The increased incidence of gastric antibodies in patients with gastritis and iron deficiency suggests that in some the hypochromic anaemia may be precipitated by recurrent small blood loss from the continuously injured mucosa.

Our findings support the view that people without pernicious anaemia may suffer from atrophic gastritis which is as severe as that in Addisonian pernicious anaemia and may be caused by some but not all of the same factors as operate in that condition. Recent family studies (Doniach et al., 1964) have shown that organ-specific autoimmunity can be demonstrated in $50 \%$ of the close relatives of probands with pernicious anaemia so providing evidence for a disturbance of the immune mechanisms in these families. The absence of intrinsic factor antibodies in the present series of patients with atrophic gastritis having no family history of pernicious anaemia contrasts with the situation in pernicious anaemia itself and this suggests that there may be some form of genetic control over the selection of antigens against which autoantibodies are developed. This possibility will be put to the test by looking for antibodies to intrinsic factor in patients with atrophic gastritis who are related to individuals suffering from pernicious anaemia.

\section{SUMMARY}

Forty-seven patients (16 males and 31 females) with gastritis diagnosed by gastric biopsy were studied. None suffered from early pernicious anaemia and in none was a family history of this condition established. Twenty-six with hypochromic anaemia and normal gastric mucosa, and healthy controls matched with the cases of atrophic gastritis, were also studied.

No patient possessed antibodies to intrinsic factor. This compares with a 40 to $60 \%$ incidence in patients with pernicious anaemia. Sixty-one per cent of female patients with atrophic gastritis had antibodies to parietal cells (compared with $89 \%$ of patients with pernicious anaemia) but only $12.5 \%$ of the small male group.

About $40 \%$ of the patients with gastritis had both gastric and thyroid antibodies. Nearly as many women with gastritis possessed thyroid antibodies as in pernicious anaemia but in the men with gastritis there was no increase above the control incidence.

There was only partial correlation between some of the gastric mucosal changes and the presence of antibodies.

Parietal cell antibodies were commoner and of higher titre when the $p \mathrm{H}$ of the gastric juice was $6 \cdot 0$ or above after histamine.

There was good correlation between severity of radioactive vitamin $B_{12}$ absorption defect and parietal cell antibody titre.

We are grateful to Professor Sir Charles Dodds, P.R.C.P., for his constant support of this work. We are greatly indebted to Mr. K. G. Couchman, Mr. C. Shapland, and Miss Susan Lee for their skilled assistance. We thank Dr. B. Pulimood for help in collecting blood samples.

\section{REFERENCES}

Abels, J., Bouma, W., Jansz, A., Woldring, M. G., Bakker, A., and Nieweg, H. O. (1963). Experiments on the intrinsic factor antibody in serum from patients with pernicious anaemia. J. Lab. clin. Med., 61, 893-906.

Adams, J. F., Glen, A. I. M., Kennedy, E. H., Mackenzie, I. L., Morrow, J. M., Anderson. J. R., Gray, K. G., and Middleton, D. G. (1964). The histological and secretory changes in the stomach in patients with autoimmunity to gastric parietal cells. Lancet, 1, 401-403.

Ardeman, S., and Chanarin, I. (1963). A method for the assay of human gastric intrinsic factor and for the detection and titration of antibodies against intrinsic factor. Ibid., 2, 13501354.

Badenoch, J., Evans, J. R., and Richards, W. C. D. (1957). The stomach in hypochromic anaemia. Brit. J. Haemat., 3, 175-185.

Baur, S., Roitt, I. M., and Doniach, D. (1965). Characterization of the human gastric parietal cell antigen. Immunology, 8 , in the press.

Bomford, R. (1938). Anaemia in myxoedema: and the role of the thyroid gland in erythropoiesis. Quart. J. Med., 7, 495-536.

Booth, C. C., and Mollin, D. L. (1956). Plasma, tissue, and urinary radioactivity after oral administration of ${ }^{56} \mathrm{Co}$-labelled vitamin $\mathrm{B}_{12}$. Brit. J. Haemat., 2, 223-236.

Charcot, M. (1881). Quoted by Bomford (1938).

Coghill, N. F. (1960). The significance of gastritis. Postgrad. med. J., 36, 733-742.

_- and Williams, A. W. (1955). Gastric biopsy with a modified Australian instrument. Brit. med. J., 2, 1111-1114.

Dacie, J. V. (1956). Practical Haematology. 2nd ed. Churchill, London.

Dagg, J. H., Goldberg, A., Anderson, J. R., Beck, J. S., and Gray, K. G. (1964). Autoimmunity in iron-deficiency anaemia. Brit. med. J., 1, 1349-1350.

Deller, D. J., and Witts, L. J. (1962). Changes in the blood after partial gastrectomy with special reference to vitamin $\mathbf{B}_{12}$. I Serum vitamin $\mathbf{B}_{12}$, haemoglobin, serum iron and bone marrow. Quart, J. Med., 31, 71-88.

Doniach, D., and Roitt, I. M. (1963). Clinical applications of thyroid autoantibody tests. In Clinical Aspects of Immunology, edited by P. G. H. Gell and R. R. A. Coombs. pp. 611-632. Blackwell, Oxford.

-1 (1964). An evaluation of gastric and thyroid autoimmunity in relation to haematological disorders. Seminars in Haemato$\log y, 1$, No. 3., in the press.

$\longrightarrow,-$ and Taylor, K. B. (1963). Autoimmune phenomena in pernicious anaemia. Serological overlap with thyroiditis, thyrotoxicosis, and systemic lupus erythematosus. Brit. med.J., 1, 1374-1379.

$-1,1964)$. Autoimmunity in pernicious anaemia and thyroiditis: a family study. Ann. N.Y. Acad. Sci., in the press.

Glass, G. B. J., Boyd, L. J., Gellin, G. A., and Stephanson, L. (1954). Uptake of radioactive vitamin $B_{12}$ by the liver in humans. Test for measurement of intestinal absorption of vitamin $\mathbf{B}_{12}$ and intrinsic factor activity. Arch. Biochem., 51, 251-257. 
Hutner, S. H., Bach, M. K., and Ross, G. I. M. (1956). A sugar containing basal medium for vitamin $\mathbf{B}_{12}$ assay with euglena: application to body fluids. J. Protozool., 3, 101-112.

Irvine, W. J., Davies, S. H., Delamore, I. W., and Williams, A. W. (1962). Immunological relationship between pernicious anaemia and thyroid disease. Brit. med. J., 2, 454-456.

Jeffries, G. H., Hoskins, D. W., and Sleisenger, M. H. (1962). Antibody to intrinsic factor in serum from patients with pernicious anaemia. J. clin. Invest., 41, 1106-1115.

Kay, A. W. (1953). Effect of large doses of histamine on gastric secretion of $\mathrm{HCl}$ : an augmented histamine test. Brit. med. J., 2, 77-80.

Mackay, I. R. (1964). Autoimmune serological studies in chronic gastritis and pernicious anaemia. Gut, 5, 23-26.

MacLean, L. D. (1957). Incidence of megaloblastic anaemia after subtotal gastrectomy. New Engl. J. Med., 257, 262-265.

McNichol, G. P. (1961). Thyrotoxicosis associated with pernicious anaemia. Amer. J. med. Sci., 241, 336-342.

Markson, J. L., and Moore, J. M. (1962a). Thyroid autoantibodies in pernicious anaemia. Brit. med. J., 2, 1352-1355.

- $-1962 \mathrm{~b})$. Autoimmunity in pernicious anaemia and iron deficiency anaemia. A complement-fixation test using human gastric mucosa. Lancet, 2, 1240-1243.

Mollin, D. L., Booth, C. C., and Baker, S. J. (1957). The absorption of vitamin $B_{12}$ in control subjects, in Addisonian pernicious anaemia and in the malabsorption syndrome. Brit. J. Haemat., 3, $412-428$.

- , and Ross, G. I. M. (1954). Vitamin $B_{12}$ deficiency in the megaloblastic anaemias. Proc. roy. Soc. Med., 47, 428-431.

Roitt, I. M., Doniach, D., and Shapland, C. (1964). Autoimmunity in pernicious anaemia and atrophic gastritis. Ann. N.Y. Acad. $\mathrm{Sci}$., in the press.

Ross, G. I. M. (1952). Vitamin $B_{12}$ assay in body fluids using euglena gracilis. J. clin. Path., 5, 250-256.
Schwartz, M. (1960). Intrinsic factor antibody in serum from patien ts with pernicious anaemia. Lancet, 2, 1263-1267.

Taylor, K. B. (1959a). Inhibition of intrinsic factor by pernicious anaemia sera. Ibid., 2, 106-108.

(1959b). An antibody to Castle's intrinsic factor: proceedings of VIIth International Congress of Haematology, Rome 1958. Haemat. lat. (Milano), 2, 181-186.

-, Roitt, I. M., Doniach, D., Couchman, K. G., and Shapland, C. (1962). Autoimmune phenomena in pernicious anaemia: gastric antibodies. Brit. med. J., 2, 1347-1352.

Tudhope, G. R., and Wilson, G. M. (1960). Anaemia in hypothyroidism. Incidence, pathogenesis, and response to treatment. Quart. J. Med., 29, 513-538.

- - (1962). Deficiency of vitamin $B_{12}$ in hypothyroidism. Lancet, 1, 703-706.

Whiteside, M. G., Mollin, D. L., Coghill, N. F., Williams, A. W., and Anderson, B. (1964). The absorption of radioactive vitamin $B_{18}$ and the secretion of hydrochloric acid in patients with atrophic gastritis. Gut, 5, 385-399.

Williams, A. W. (1960). Quoted by Coghill (1960).

-, Edwards, F., Lewis, T. H. D., and Coghill, N. F. (1957). Investigation of non-ulcer dyspepsia by gastric biopsy. Brit. med. J., 1, 373-377.

Williams, E. D., and Doniach, I. (1962). The post-mortem incidence of focal thyroiditis. J. Path. Bact., 83, 255-264.

Witts, L. J. (1956) Anaemia and the alimentary tract: the relationship between changes in the alimentary tract and deficiencies of iron, folic acid and vitamin $\mathbf{B}_{12}$. The Sydney Watson Smith Lecture, The Royal College of Physicians, Edinburgh, 1955.

Wood, I. J., Doig, R. K., Motteram, R., and Hughes, A. (1949). Gastric biopsy: report on fifty-five biopsies using a new flexible gastric biopsy tube. Lancet, 1, 18-21.

-, Ralston, M., Ungar, B., and Cowling, D. C. (1964). Vitamin B B $_{12}$ deficiency in chronic gastritis. Gut, 5, 27-37. 